\title{
Authenticity and drug resistance in a panel of acute lymphoblastic leukaemia cell lines
}

\author{
AH Beesley ',4, M-L Palmer',2,4, J Ford', RE Weller', AJ Cummings', JR Freitas', MJ Firth ${ }^{3}$, KU Perera ${ }^{3}$, \\ NH de Klerk ${ }^{3}$ and UR Kees ${ }^{*, 1}$
}

'Division of Children's Leukaemia and Cancer Research, Telethon Institute for Child Health Research, and Centre for Child Health Research, University of Western Australia, Perth, Australia; ${ }^{2}$ Curtin University of Technology School of Pharmacy, Perth, Western Australia; ${ }^{3}$ Division of Biostatistics and Genetic Epidemiology, Telethon Institute for Child Health Research, and Centre for Child Health Research, University of Western Australia, Perth, Australia

\begin{abstract}
Cell lines are important models for drug resistance in acute lymphoblastic leukaemia (ALL), but are often criticised as being unrepresentative of primary disease. There are also doubts regarding the authenticity of many lines. We have characterised a panel of ALL cell lines for growth and drug resistance and compared data with that published for primary patient specimens. In contrast to the convention that cell lines are highly proliferative, those established in our laboratory grow at rates similar to estimates of leukaemic cells in vivo (doubling time 53-442 h). Authenticity was confirmed by genetic fingerprinting, which also demonstrated the potential stability of long-term cultures. In vitro glucocorticoid resistance correlated well with that measured ex vivo, but all lines were significantly more sensitive to vincristine than primary specimens. Sensitivity to methotrexate was inversely correlated to that of glucocorticoids and L-asparaginase, indicating possible reciprocity in resistance mechanisms. A cell line identified as highly methotrexate resistant ( $\left(\mathrm{C}_{50}>8000\right.$-fold higher than other lines) was derived from a patient receiving escalating doses of the drug, indicating in vivo selection of resistance as a cause of relapse. Many of these lines are suitable as models to study naturally occurring resistance phenotypes in paediatric ALL.

British Journal of Cancer (2006) 95, 1537- 1544. doi: I 0. I038/sj.bjc.6603447 www.bjcancer.com

Published online 2I November 2006

(c) 2006 Cancer Research UK
\end{abstract}

Keywords: acute lymphoblastic leukaemia; drug resistance; cell line; methotrexate; glucocorticoid; fingerprint

In children with acute lymphoblastic leukaemia (ALL) cellular drug sensitivity is a major component of clinical outcome. This is true not only for relapsed ALL (Klumper et al, 1995) where in vivo selection of resistant clones occurs during therapy, but also in those newly diagnosed with the disease (Kaspers et al, 1997; Pieters et al, 1998). Much of our knowledge of the resistance phenotypes in ALL has been derived using isolated bone marrow specimens studied in short-term culture using the 3-(4,5-dimethylthiazol2-yl)-2,5-diphenyltetrazolium bromide (MTT) assay. However, application of this ex vivo approach for functional studies or drug screening is limited by both the availability of patient material and the short period of survival of these cells in culture. Furthermore, this approach cannot be used to measure methotrexate (MTX) resistance in such specimens because the high rate of spontaneous cell death releases nucleosides in sufficient quantity to prevent MTX cytotoxicity (Pieters et al, 1997). Investigation of resistance mechanisms and evaluation of novel drug-leads invariably requires the use of immortalised cell lines, but the extent to which these cells retain features of the original disease in vivo is a matter of some debate (Kamb, 2005), a problem exemplified by the typically high growth rates of continuous cultures (Masters, 2000). Added to this is concern over the alarming frequency with which cultures

\footnotetext{
*Correspondence: Professor UR Kees; E-mail: ursula@ichr.uwa.edu.au

${ }^{4} \mathrm{AHB}$ and MLP share equal first authorship

Received 27 June 2006; revised 20 September 2006; accepted 26 September 2006; published online 21 November 2006
}

have been found retrospectively to be infected with mycoplasma or cross-contaminated with other cell lines (so-called 'false' lines) (Masters, 2000; Drexler et al, 2003). This has led to repeated calls for the extensive characterisation and validation of authenticity of such cell lines (Drexler and Matsuo, 1999; Masters et al, 2001; Drexler et al, 2002, 2003).

Over the past 20 years our laboratory has developed a panel of paediatric ALL cell lines that have been grown in the absence of drug selection. Previously, we have shown, using a subset of this panel, that these cultures retain critical immunophenotypic and molecular features of the primary disease (Kees et al, 2003). Here, we have validated the genetic identity of these lines and have systematically studied their drug resistance and growth profiles to assess the degree to which they reflect the phenotype of primary ALL patient specimens.

\section{MATERIALS AND METHODS}

\section{Cell lines}

PER cell lines were derived from paediatric ALL bone marrow specimens as described previously (Kees et al, 1987). Patients were diagnosed and treated at the Princess Margaret Hospital for Children, Perth, Western Australia, and informed consent was obtained from parents, patients, or both as deemed appropriate. Several of the cell lines have been described previously (Kees, 1987; Kees et al, 1987, 1989a, b, 1990, 1995, 2003; Kennedy et al, 1991; 
Whitman et al, 2001). CCRF-HSB2 (HSB2) cells were obtained from the American Type Culture Collection; CCRF-CEM (CEM) from the Children's Cancer Institute Australia for Medical Research, Sydney; JURKAT from the Basel Institute for Immunology, Switzerland; ALL-SIL from MRC Laboratory of Molecular Biology, Cambridge, UK; MOLT4 from the German Cancer Research Center, Heidelberg, Germany; DU.528 from the Division of Cancer Biology, Telethon Institute for Child Health Research, Perth. Cell lines were grown in RPMI-1640 supplemented with $2 \mathrm{~mm}$ L-glutamine, $10 \mathrm{~nm}$ 2-mercaptoethanol and $10-20 \%$ heatinactivated foetal calf serum. All PER cell line media contained additional non-essential amino acids and pyruvate, whereas $300 \mathrm{U} /$ $\mathrm{ml}$ interleukin-2 is required for growth of PER-427 and PER-487 (Kees et al, 2003). Cell lines were cultured in the absence of antibiotics; testing for mycoplasma was routinely performed by PCR, and immunophenotyping performed by indirect immunofluorescence and flow cytometry (Kees et al, 1987, 2003). Doubling times were determined using the MTT assay (described below) and extensive laboratory records. DNA fingerprinting of matched cell lines and patient specimens was performed by Genetic Technologies Corporation Pty Ltd (Melbourne, Australia) using the AmpF/short tandem repeat (STR) Identifiler kit which co-amplifies 15 STR loci and the sex determination locus Amelogenin. Allelic profiles were assessed by calculating the percentage of alleles at the 16 loci present in cell lines that were also co-identified in the corresponding patient specimen (Supplementary Table 1).

\section{In vitro drug resistance}

Resistance was tested using the MTT assay (Alley et al, 1988). Cells in exponential growth phase were counted by trypan blue exclusion and seeded in fresh media at a density of $5 \times 10^{5}$ $1.5 \times 10^{6} \mathrm{cells} \mathrm{ml}^{-1}$ in a 96 -well plate in the presence or absence of each drug. Drugs were serially diluted in fresh media, with each drug concentration tested in triplicate. Culture plates were incubated for 4 days at $37^{\circ} \mathrm{C}$ before the addition of $10 \mu \mathrm{l}$ of filter-sterilised MTT $\left(5 \mathrm{mg} \mathrm{ml}^{-1}\right)$. Plates were re-incubated for $6 \mathrm{~h}$ before addition of $100 \mu \mathrm{l}$ of acidified isopropyl alcohol solution to dissolve formazan crystals and measurement of absorbance at $590 \mathrm{~nm}$. Testing was performed using two-fold step dilutions of the following drug ranges: cytosine arabinoside (ARA-C; Pharmacia Pty Ltd, NSW, Australia) $0.3 \mathrm{pg} \mathrm{ml}^{-1}-2.5 \mu \mathrm{g} \mathrm{ml}^{-1}$; dexamethasone (DEX; Mayne Pharma Pty Ltd, VIC, Australia) $30 \mathrm{pg} \mathrm{ml}^{-1}$ $250 \mu \mathrm{g} \mathrm{ml}^{-1}$; methylprednisolone (MPRED; David Bull Laboratories, VIC, Australia) $30 \mathrm{pg} \mathrm{ml}^{-1}-250 \mu \mathrm{g} \mathrm{ml}^{-1}$; 6-thioguanine (6TG; GlaxoSmithKline Australia Pty Ltd, VIC, Australia) $12 \mathrm{pg} \mathrm{ml}^{-1}-100 \mu \mathrm{g} \mathrm{ml}^{-1}$; 6-mercaptopurine (6MP; GlaxoSmithKline) $60 \mathrm{pg} \mathrm{ml}^{-1}-500 \mu \mathrm{g} \mathrm{ml}^{-1}$; daunorubicin (DNR; Pharmacia) $0.2 \mathrm{pg} \mathrm{ml}^{-1}-2 \mu \mathrm{g} \mathrm{ml}^{-1}$; doxorubicin (DOX; Mayne Pharma Pty Ltd) $1 \mathrm{pg} \mathrm{ml}^{-1}-8 \mu \mathrm{g} \mathrm{ml}^{-1}$; L-asparaginase (ASP; Kyowa Hakko Kogyo Co. Ltd, Tokyo) $2.4 \times 10^{-6}-20 \mathrm{IU} \mathrm{ml}^{-1}$; vincristine (VCR; Pharmacia) $23 \mathrm{fg} \mathrm{ml}^{-1}-195 \mathrm{ng} \mathrm{ml}^{-1}$; methotrexate (MTX; David Bull Laboratories) $60 \mathrm{pg} \mathrm{ml}^{-1}-500 \mu \mathrm{g} \mathrm{ml}^{-1}$. The $\mathrm{IC}_{50}$ (drug concentration that inhibits cell growth by $50 \%$ ) was used as the measure of drug resistance. Data represent the average of 2-6 separate experiments and linearity was checked between viable cell number and optical density for each cell line. Where $50 \%$ cytotoxicity was not achieved by even the highest dose, the $\mathrm{IC}_{50}$ was recorded as double the highest concentration tested.

\section{Comparison of in vitro and ex vivo resistance profiles}

Data from multiple studies (Pieters et al, 1990, 1991, 1998; Klumper et al, 1995; Duyn et al, 1999; Styczynski et al, 2000, 2002, 2005; Zwaan et al, 2000; Mihal et al, 2004; Fine et al, 2005; Kaspers et al, 2005; Steinbach et al, 2005) were combined to determine an absolute minimum and maximum $\mathrm{IC}_{50}$ range for bone marrow specimens obtained from paediatric ALL patients at the time of diagnosis (PD) or relapse (PR). Data reported in these studies as $\mathrm{LC}_{50}$ values are, for simplicity, referred to here in terms of $\mathrm{IC}_{50}$. Eligible studies satisfied the following criteria: (i) drug sensitivity was tested in primary ALL specimens using the MTT assay; (ii) drug incubation was for 3-5 days with no exposure to other agents before testing; (iii) resistance was reported using $\mathrm{IC}_{50}$ or $\mathrm{LC}_{50}$ values; (iv) patients were under 19 years of age and were divided into diagnosis and relapse cohorts. In the two cases where patients were stratified by immunophenotype (Pieters et al, 1998; Kaspers et al, 2005), data from T- and B-lineage specimens were combined before analysis. Data for MPRED were available from only one study (Styczynski et al, 2002), Whilst MTX sensitivity cannot be measured in primary specimens using the MTT assay (Pieters et al, 1997).

\section{Statistical analysis}

All comparisons were performed on $\log _{2} \mathrm{IC}_{50}$ data; the EpsteinBarr virus (EBV)-transformed cell line PER-607 was not included in any of the analyses. Significant differences in $\mathrm{IC}_{50}$ values between drugs (in molarity) were determined using the nonparametric Wilcoxon-matched pairs signed ranks test. All other differences were assessed using the Mann-Whitney $U$-test. Spearman's correlations were used to assess relationships between drug profiles ( $\mathrm{IC}_{50}$ values). Delta $\mathrm{IC}_{50}$ profiles for MPRED, DEX, ASP and MTX were calculated by subtracting median $\log _{2} \mathrm{IC}_{50}$ values (T-ALL cell lines, $n=15$ ) from the $\log _{2} \mathrm{IC}_{50}$ score for each cell line.

\section{RESULTS}

\section{Characterisation of cell lines}

The 17 cell lines developed in our laboratory are listed in Table 1. The panel comprises nine T-ALL and seven B-lineage ALL lines derived from children at different stages of disease (diagnosis or relapse), and one EBV-transformed cell line (PER-607) which was originally derived from the diagnostic specimen of a patient that expressed both T- and B-cell markers. The cell line demonstrated a B-lineage immunophenotype and the presence of EBV was confirmed by PCR. DNA fingerprinting verified the genetic identity of the cell lines, with 13 out of 17 lines showing $100 \%$ allelic concordance with original patient specimens across 16 genomic loci (Table 1 and Supplementary Table 1). The minor allelic variations we observed in four lines (88-97\% concordant) are consistent with the genetic drift associated with cancer cells grown in culture over extended periods (Masters et al, 2001). The primary patient specimen for PER-117 demonstrated additional (tertiary) alleles in low abundance at several loci (6 out of 16 loci), which were not present in the DNA from PER-117 (Supplementary Table 1). This specimen was obtained from a patient who relapsed 2 months after receiving a bone marrow transplant from his brother; the minor alleles are indicative of the presence of residual donor cells in the marrow aspirate at relapse.

\section{Cell line drug resistance profiles}

The cell lines in Table 1 and six additional T-ALL cell lines obtained from external sources, were tested for their sensitivity to the 10 drugs most commonly used in the treatment of paediatric ALL. The $\mathrm{IC}_{50}$ values for each cell line are listed in Table 2 along with their doubling time for growth in culture. The experimental protocol (i.e. measurement by MTT assay after a 4-day drug incubation) was modelled on the approach successfully used to assess drug resistance in primary ALL bone marrow specimens ex vivo (Klumper et al, 1995; Kaspers et al, 1997, 2005). For most drugs, sensitivities ranged over several orders of magnitude. The EBV-transformed cell line PER-607 had relatively high $\mathrm{IC}_{50}$ values 


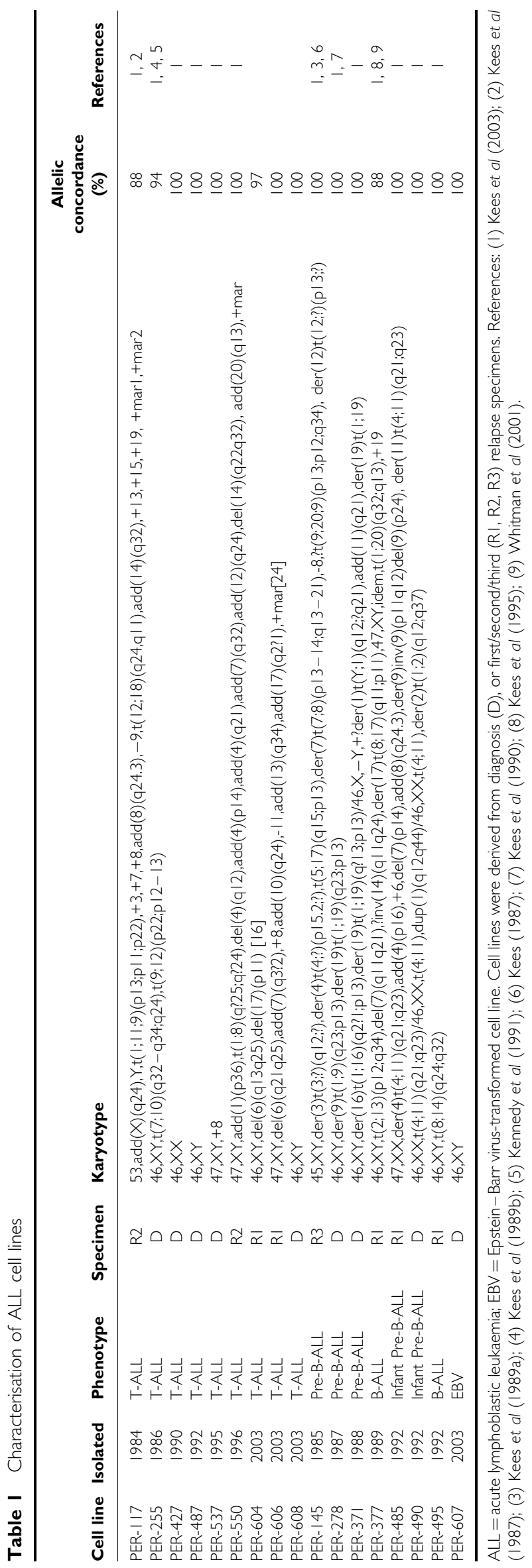

for most of the drugs tested, although these were still within the range demonstrated for ALL lines. Although included here for general interest, the drug resistance profile of this cell line was not included in subsequent analyses.

The resistance profiles of the 15 T-ALL and seven B-lineage ALL cell lines are shown graphically in Figure 1. Among T-ALL lines (open boxes), greatest resistance was to the steroids (DEX and MPRED) and thiopurines (6MP and 6TG) with median $\mathrm{IC}_{50}$ values several orders of magnitude higher than the other drugs; greatest sensitivity was to VCR and ASP. A similar drug profile was observed in the B-lineage cell lines (Figure 1, shaded boxes). The parental CCRF-CEM cell line is known to represent a mixed population of sensitive and resistant clones (Medh et al, 2003); $\mathrm{IC}_{50}$ values for DEX and ASP for this cell line (Table 2) were much higher than have been reported elsewhere (Martin-Aragon et al, 2000; Catts et al, 2001; van der Heijden et al, 2004), indicating that our CEM represents a resistant sub-clone that has grown out during culture.

Although there were considerable differences in medians between the T- and B-lineage ALL cell lines for some drugs, particularly DEX and ASP, these did not reach statistical significance owing to the considerable variation observed within each lineage (Mann-Whitney $U$-test, $P>0.05$ ). Previous work in primary specimens has indicated that T-ALL specimens are more resistant than precursor B-lineage to several front-line drugs, especially ASP, VCR and glucocorticoids (Pieters et al, 1998). Although the trend for DEX in our data is in agreement with these findings, for the other drugs, particularly ASP, this is not the case. Larger in vitro studies are required to confirm these findings.

Daunorubicin was approximately three times more potent than DOX in both lineages (Wilcoxon-matched pairs test: T-ALL, $P<0.001$; B-lineage ALL, $P=0.018$; $\mathrm{T}$ and $\mathrm{B}$ lineages combined, $P<0.0001$ ), whereas $6 \mathrm{TG}$ was $6-24$ times more cytotoxic than $6 \mathrm{MP}$ (Wilcoxon-matched pairs test: T-ALL, $P<0.005$; B-lineage ALL, $P<0.05 ; \mathrm{T}$ and $\mathrm{B}$ lineages combined, $P<0.0005)$. These observations are consistent with previous reports of the in vitro cytotoxicity of these agents (Adamson et al, 1994; Klumper et al, 1995; Pieters et al, 1998; Kaspers et al, 2005). No significant differences in cytotoxicity were observed between DEX and MPRED $(P>0.05)$.

An increase in resistance to many front-line drugs, particularly the glucocorticoids, has been reported at the time of ALL relapse (Klumper et al, 1995; Rots et al, 2000), the phenomenon being most pronounced in those with pre-B-ALL (Kaspers et al, 2005). In the present study, there was no significant difference in drug sensitivity between cell lines derived from diagnosis or relapse specimens, but there was a trend towards increased steroid resistance in B-ALL lines derived from relapse patient (Table 1).

\section{Comparison of in vitro and in vivo drug resistance}

To assess how the spectrum of drug resistance observed in the cell line panel related to levels of resistance found in patients, we compared our data with that published from ex vivo studies of primary paediatric ALL specimens. The studies included in this analysis are shown in Table 3 and were selected using strict criteria for experimental design, both to minimise variations caused by laboratory handling and to facilitate comparison with data obtained in the present study (see Materials and Methods). As most of the published data were not stratified for immunophenotype, data for T- and B-lineage cell lines were combined for this analysis. The data are compared with cell line resistance profiles in Figure 2, with the medians from the multiple studies indicated by individual tick marks. Studies of primary ALL specimens have consistently indicated an increase in median glucocorticoid resistance at relapse (Figure 2, PR), yet some patients are highly resistant to these agents even at the time of first diagnosis 
Table 2 Growth and drug resistance profile of ALL cell lines

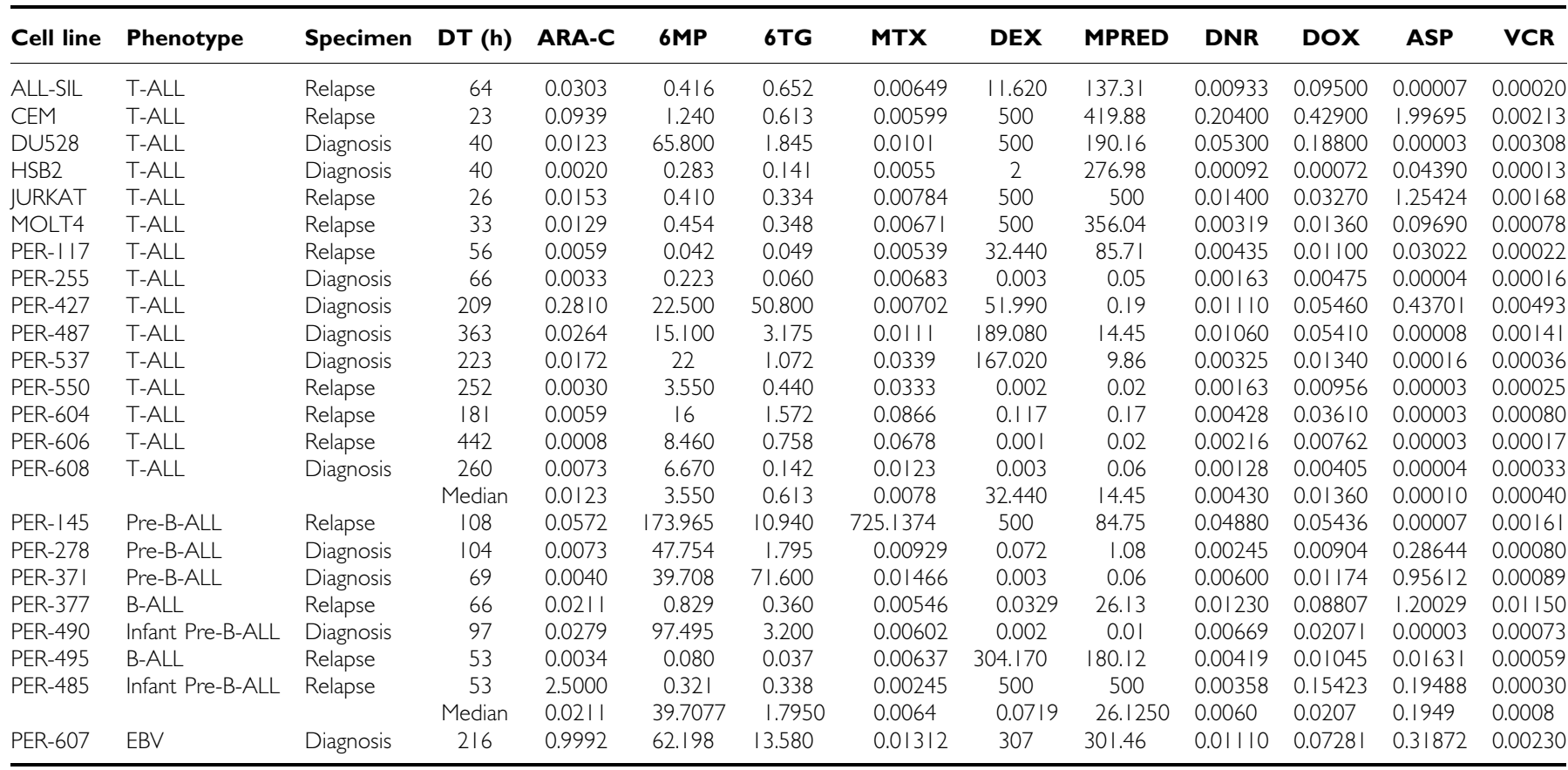

$\mathrm{ALL}=$ acute lymphoblastic leukaemia; $\mathrm{ARA}-\mathrm{C}=$ cytosine arabinoside; $\mathrm{ASP}=\mathrm{L}$-asparaginase; $\mathrm{DEX}=$ dexamethasone; $\mathrm{DNR}=$ daunorubicin; $\mathrm{DOX}=\mathrm{dox}$ rubicin; $\mathrm{DT}=$ doubling time; $\mathrm{EBV}=$ Epstein - Barr virus-transformed cell line; $6 \mathrm{MP}=6$-mercaptopurine; $\mathrm{MTX}=$ methotrexate; $6 \mathrm{TG}=6$-thioguanine; $\mathrm{MPRED}=$ methylprednisolone; $\mathrm{VCR}=$ vincristine. $I_{50}$ units are $\left.\mu \mathrm{g} \mathrm{ml}\right|^{-1}$, except for ASP $\left(I \cup \mathrm{ml}^{-1}\right)$.

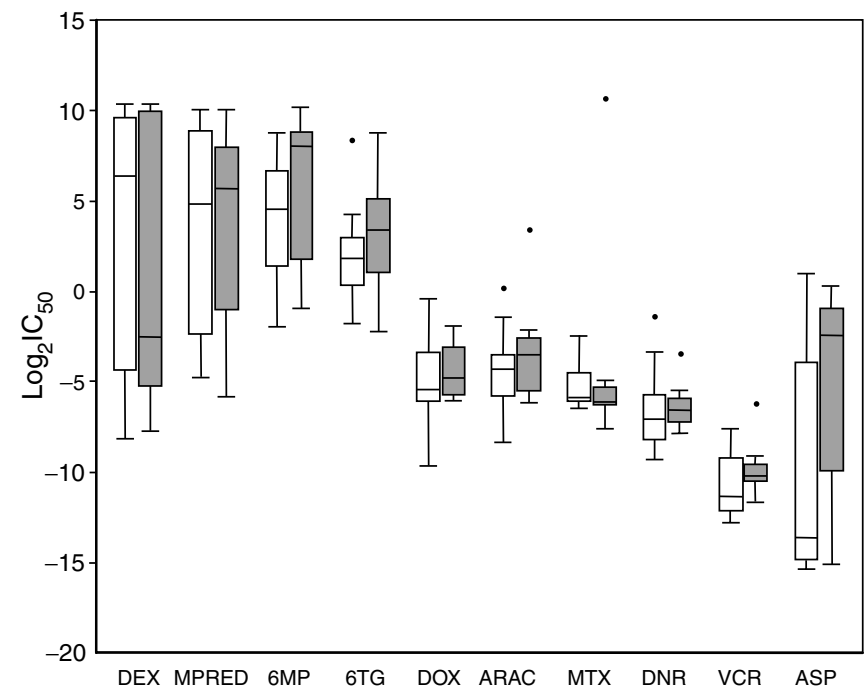

Figure I Drug resistance profile of $A L L$ cell lines. $I C_{50}$ values for $T-A L L$ (open, $n=15$ ) vs B-lineage ALL (shaded, $n=7$ ) cell lines. Boxes indicate medians and inter-quartile range, whiskers indicate 10th and 90th percentiles and dots indicate outliers; values are calculated as $\log _{2}$ molarity $(\mu \mathrm{M})$ for all drugs, except ASP which is given as $\log _{2} \mathrm{IU} \mathrm{ml}^{-1}$.

(Figure 2, PD), with the maximum reported range for DEX being similar in both cases. For the other compounds in Figure 2, diagnosis and relapse resistance profiles overlap significantly reiterating the particular importance of steroid resistance in relapsing patients. Among the cell lines (CLD/CLR), some were particularly resistant to $\mathrm{DEX}$, exceeding $\mathrm{LC}_{50}$ values reported for even the most resistant relapse patient (Figure 2 and Table 2). However, the highest dose tested in the patient studies was $6 \mu \mathrm{g} \mathrm{ml}^{-1}$, many times lower than the maximum dose used in the present study $\left(250 \mu \mathrm{g} \mathrm{ml}^{-1}\right)$ and so the reported $\mathrm{LC}_{50}$ range for patients at relapse is likely to be an underestimate.
All cell lines, without exception, were significantly more sensitive to VCR than patient specimens. Lines were also more sensitive to ASP, 6MP and DOX than primary specimens (primarily owing to lower values in T-ALL cell lines, see Figure 1), although these differences were not as extreme. Data for MTX resistance measured using the MTT assay in primary specimens are not available. Methotrexate sensitivities have been successfully compared in primary specimens using in situ inhibition of thymidylate synthetase (Rots et al, 2000), but the data are not comparable to the growth inhibition studies performed in the present study. However, peak plasma concentrations after a $20 \mathrm{mg} \mathrm{m}^{-2}$ oral dose range from 0.1 to $1.4 \mu \mathrm{g} \mathrm{ml}^{-1}$ (Balis et al, 1998), and in comparison to this, all cell lines with the exception of PER-145 were relatively sensitive (Table 2). PER-145 was extraordinarily resistant to MTX, having an $\mathrm{IC}_{50}>8000$ times higher than even the next most resistant cell line.

\section{Cross-resistance between drugs}

Spearman's correlations were used to identify drugs with similar profiles across the T-ALL cell line panel, which represents a larger and more homogenous group than the B-lineage cell lines. $\mathrm{IC}_{50}$ scores for drugs with a similar mechanism of action (Table 4, boxed) were highly correlated to each other (DEX vs MPRED, DNR vs DOX and 6MP vs 6TG, all $P<0.001$ ), demonstrating that this is a valid approach for the identification of potential cross-resistance between compounds, although it should be emphasised that these relationships were not directly tested in the present study. DEX showed significant correlation (bold values, $P<0.05$ ) to all drugs, except MTX and the thiopurines; MPRED mirrored this pattern, particularly in regard to ASP, DNR and MTX, the latter showing an inverse relationship as it did with DEX. The relationship between MPRED, DEX, ASP and MTX in the T-ALL cell lines is demonstrated graphically in Figure 3, which displays the resistance spectrum of the panel for each of the four drugs. The Delta $\mathrm{IC}_{50}$ score used in this analysis essentially ranks the cell lines for their resistance in comparison to the population median (positive scores 
Table 3 Details of ex vivo resistance studies used for comparison with in vitro data

\begin{tabular}{|c|c|c|c|c|c|}
\hline Drug & No. of studies & $\begin{array}{l}\text { No. of diagnosis } \\
\text { specimens }\end{array}$ & $\begin{array}{l}\text { No. of relapse } \\
\text { specimens }\end{array}$ & $\begin{array}{l}\text { Total No. of } \\
\text { specimens }\end{array}$ & References \\
\hline DEX & 7 & 737 & 248 & 985 & $1,2,5,8,9,11,13$ \\
\hline ARA-C & 9 & 995 & 331 & 1326 & $1-3,5,8,10-13$ \\
\hline $6 \mathrm{MP}$ & 5 & 764 & 220 & 984 & $1,2,5,8,11$ \\
\hline 6TG & 9 & 973 & 291 & 1264 & $1-3,5,7,8,11-13$ \\
\hline ASP & 7 & 1013 & 275 & 1288 & $1,2,4,5,8,11-12$ \\
\hline
\end{tabular}

ARA-C = cytosine arabinoside; $A S P=L$-asparaginase; $D E X=$ dexamethasone; $D N R=$ daunorubicin; $D O X=$ doxorubicin; $6 \mathrm{MP}=6$-mercaptopurine; $6 \mathrm{TG}=6$-thioguanine; MPRED = methylprednisolone; VCR = vincristine. References: (I) Klumper et al (1995); (2) Pieters et al (1998); (3) Duyn et al (1999); (4) Fine et al (2005); (5) Kaspers et al (2005); (6) Mihal et al (2004); (7) Pieters et al (199I); (8) Styczynski et al (2000); (9) Styczynski et al (2002); (10) Styczynski et al (2005); (I I) Zwaan et al (2000); (I2) Pieters et al (1990); (13) Steinbach et al (2005).
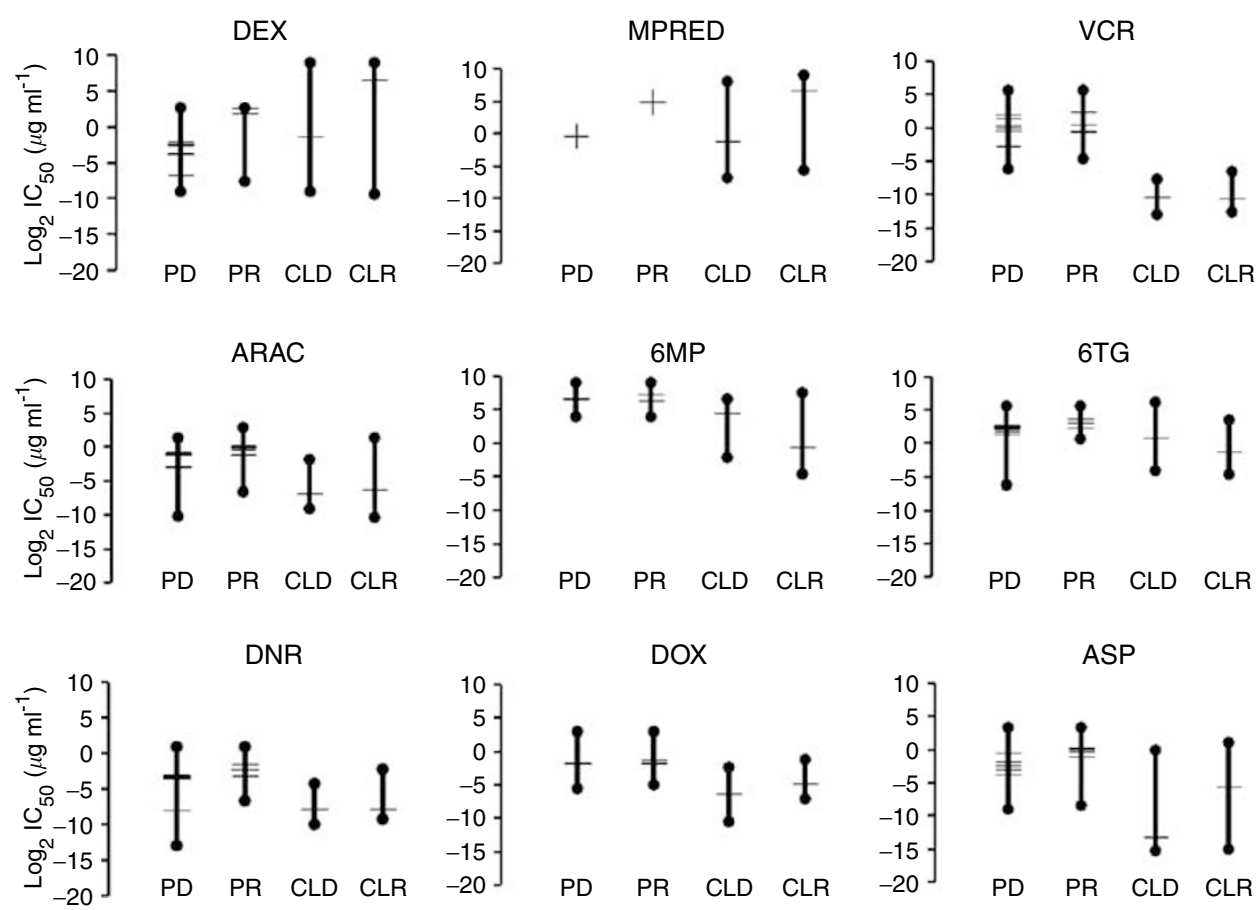

Figure 2 Comparison of resistance profiles in patients and cell lines. Data indicate total $I_{50}$ ranges determined from published studies of diagnosis (PD) and relapse (PR) patient specimens, and from cell lines derived from diagnosis (CLD) and relapse (CLR) specimens in the present study. Median values from individual studies are indicated as tick marks. Median values from the single study of MPRED resistance in patient specimens are indicated as crosses. Data represent combined $T$ and $B$ lineages; values are $\left.\mu \mathrm{gml}\right|^{-1}$ for all drugs, except ASP which is given as $I \cup \mathrm{ml}^{-1}$.

Table 4 Cross-correlation of drug-resistance $\left(\mathrm{IC}_{50}\right)$ profiles in I5 T-ALL cell lines

\begin{tabular}{|c|c|c|c|c|c|c|c|c|c|c|}
\hline & DEX & MPRED & ASP & MTX & DNR & DOX & VCR & ARAC & 6TG & 6MP \\
\hline DEX & - & 0.85 & 0.59 & -0.35 & 0.74 & 0.67 & 0.71 & 0.70 & 0.24 & 0.14 \\
\hline MPRED & 0.85 & - & 0.68 & -0.62 & 0.54 & 0.46 & 0.37 & 0.48 & -0.11 & -0.26 \\
\hline DNR & 0.74 & 0.54 & 0.34 & -0.17 & - & 0.91 & 0.78 & 0.73 & 0.50 & 0.29 \\
\hline DOX & 0.67 & 0.46 & 0.21 & -0.09 & 0.91 & - & 0.76 & 0.77 & 0.65 & 0.42 \\
\hline VCR & 0.71 & 0.37 & 0.29 & 0.15 & 0.78 & 0.76 & - & 0.69 & 0.63 & 0.61 \\
\hline $6 \mathrm{MP}$ & 0.14 & -0.26 & -0.32 & 0.68 & 0.29 & 0.42 & 0.61 & 0.28 & 0.89 & - \\
\hline
\end{tabular}

$\mathrm{ALL}=$ acute lymphoblastic leukaemia; $A R A-C=$ cytosine arabinoside; $A S P=L$-asparaginase; $D E X=$ dexamethasone; $D N R=$ daunorubicin; $D O X=$ doxorubicin; $6 M P=6$ mercaptopurine; $\mathrm{MTX}=$ methotrexate; $6 \mathrm{TG}=6$-thioguanine; $\mathrm{MPRED}=$ methylprednisolone; $\mathrm{VCR}=$ vincristine. Boxes indicate drugs paired by compound class; Bold entries, $P<0.05$. 

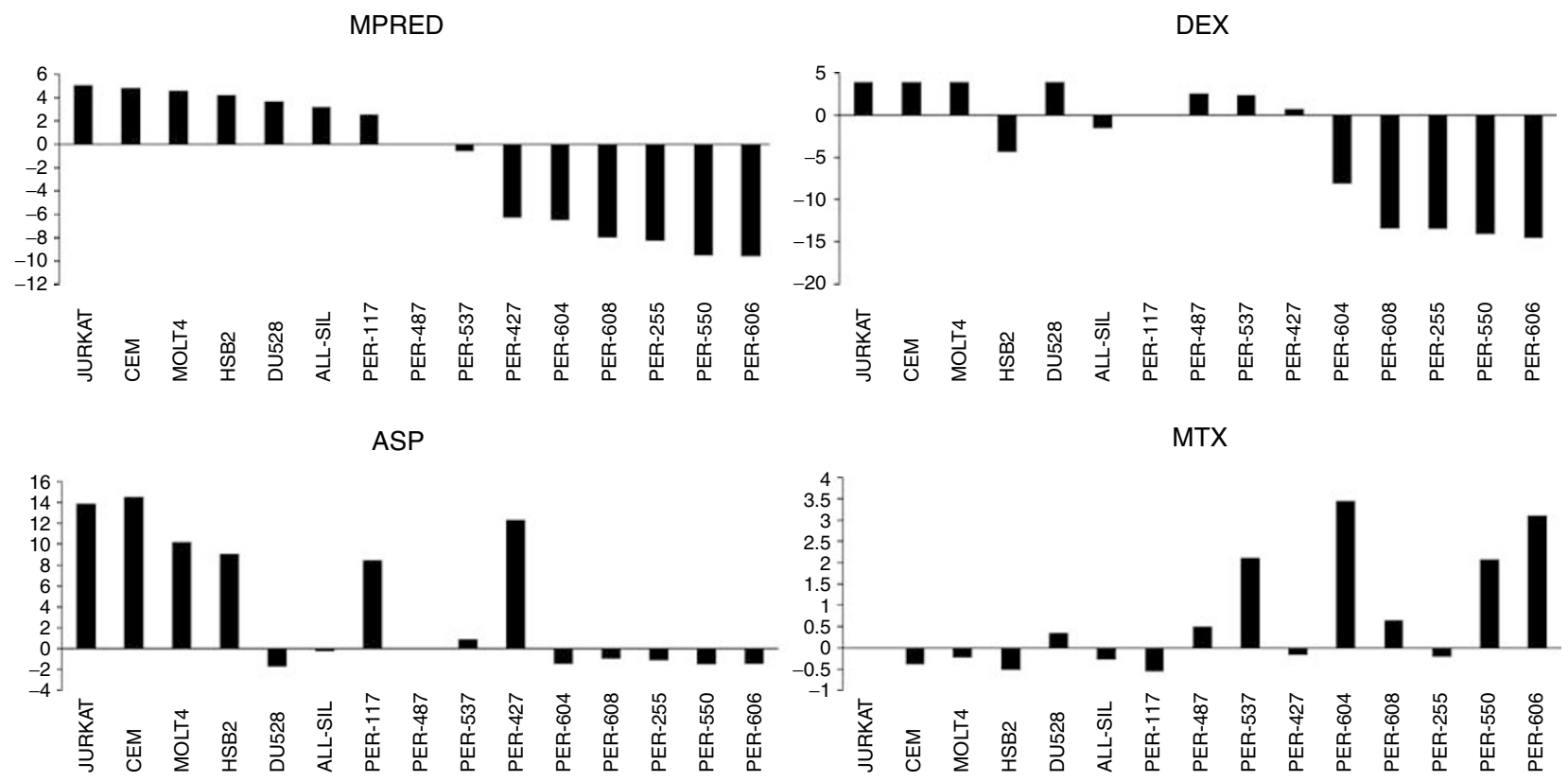

Figure 3 Resistance profiles of MPRED, DEX, ASP and MTX in T-ALL cell lines. Delta IC 50 scores ( $\log _{2} I C_{50}-$ median Log $I_{50}$ ) were calculated for each drug and cell lines plotted from left to right according to their Delta $I C_{50}$ rank for MPRED.

more resistant than the median, negative scores more sensitive than the median). Cell lines resistant to MPRED, DEX and ASP were generally the most sensitive to MTX and vice versa $(P<0.05$ for negative correlation between MTX and ASP, Table 4). Resistance profiles to the anthracyclines (DNR and DOX), ARA-C and VCR were all significantly correlated to each other in T-ALL cell lines (Table 4 , all $P \leqslant 0.005$ ), indicating cross-resistance.

\section{DISCUSSION}

A frequent criticism of cancer cell lines is that they are unrepresentative of the primary disease as they originate from highly proliferative cell populations that are particularly amenable for growth in culture (Masters, 2000). This is exemplified by the six cell lines included in this study that were obtained from external sources, all of which grow quickly and are easy to maintain (Table 2). In contrast, many of our own cell lines are slow growing and were extremely difficult to establish. Notably, our panel represents an unselected cohort of patients, with half of the lines originating from diagnostic specimens. The doubling time of non-leukaemic pre-B cells measured ex vivo is $\sim 65-90 \mathrm{~h}$, whereas leukaemic pre-B cells are thought to be more heterogeneous, ranging from 25 to $240 \mathrm{~h}$ (Hirt et al, 1992; Cooperman et al, 2004); primary leukaemic T-ALL cells have a similar growth profile (Hirt et al, 1992). The wide range of growth rates among the cell line panel $(23-442 \mathrm{~h}$, Table 2$)$ mirrors these reported values, indicating that they may be closer to the in vivo situation than is commonly believed for such cell lines. In accordance with published guidelines (Drexler and Matsuo, 1999; Drexler et al, 2003), we have validated the authenticity of these cell lines by genetic fingerprinting. Despite the fact that some were isolated up to 20 years ago, there was an impressive degree of concordance with the primary specimens from which they were derived, indicating a high degree of stability in long-term routine culture.

In this study, we have not directly tested the drug resistance profiles of the patient specimens from which our cell lines were derived. However, comparison with previously published data indicates that for each of the drugs tested here, except VCR, there are several cell lines within the panel that accurately reflect the sensitivity of leukaemic blasts tested ex vivo; for DEX, ARA-C, 6TG and DNR, the overlap between in vitro and ex vivo data is particularly strong. The lines included in this study have always been maintained without selection pressure (i.e. are grown without antibiotics and have had no drug exposure before MTT testing) and thus represent an ideal model system for the investigation of resistance mechanisms that may occur naturally in vivo; to this end, experiments are underway to examine the gene-expression profile of the panel by high-density oligonucleotide microarray. However, the consistent hypersensitivity of all cell lines to VCR may be an indication that in vitro studies of resistance for this drug should be interpreted with caution. The observation cannot be explained as an artefact of high proliferation rates in culture as many of these lines are extremely slow growing (Table 2), but may instead be a reflection of the well-documented inoculum effect whereby VCR cytotoxicity is increased at lower cell densities (Kobayashi et al, 1998). Alternatively, adaptation to an in vitro microenvironment may mitigate changes to cell architecture that render the cell more sensitive to the microtubule-blocking effects of VCR.

PER-145 was found to be highly resistant to MTX and had relatively high $\mathrm{IC}_{50}$ values for all of the drugs, except ASP for which it appears to have retained sensitivity (Table 2). This cell line has a complex karyotype (Table 1) and was derived from a patient who had received escalating doses of MTX (as per the Capizzi I schedule) in the 5 weeks immediately before his third relapse; the cell line was isolated from this third relapse specimen and has presumably undergone selection for MTX resistance in vivo. The patient subsequently relapsed for a fourth time after having received high-dose ARA-C; a description of an additional cell line isolated from this later time point and demonstrating resistance to ARA-C has previously been published (Kees, 1987; Kees et al, 1989a). The retention of ASP sensitivity in PER-145 may be related to the fact that this cell line carries the TEL-AML1 translocation (Kees et al, 2003), which has been linked to increased ASP sensitivity in ALL (Ramakers-van Woerden et al, 2000). Closer examination of the mechanism for MTX resistance in this cell line is currently underway.

In T-ALL cell lines, there was significant $\mathrm{IC}_{50}$ correlation between DNR, DOX, VCR and ARA-C, consistent with previous 
studies indicating mechanisms of cross-resistance for these drugs (Kaspers et al, 1998; Martin-Aragon et al, 2000; Lofgren et al, 2004). We found a positive correlation between glucocorticoid and ASP resistance, indicating that sensitivity to these unrelated compounds may also be influenced by common biological factors, possibly through alterations in apoptosis (Holleman et al, 2003). There was no correlation between the glucocorticoids and thiopurines, but between glucocorticoids and MTX there was in fact evidence of an inverse relationship. Lack of cross-resistance between MTX and glucocorticoids has previously been highlighted by a small study in ALL patient specimens (Hegge et al, 1999) but, to the best of our knowledge, a directly inverse relationship as indicated by the present data has not yet been described. It is interesting to speculate that this phenomenon may relate to differential expression of specific multidrug transporters, for example the coordinated upregulation of ABCG2 (breast cancer resistance protein or $\mathrm{BCRP}$ ) and downregulation of $\mathrm{ABCC} 1$ (MRP1); such changes have recently been associated with reciprocal changes in the sensitivities to DEX and MTX in CEM cells (1.8-fold increase in resistance to MTX, and a 13-fold decrease in resistance to DEX (van der Heijden et al, 2004)). The ratio of these same drug transporters is also important for MTX pharmacodynamics in paediatric ALL (Kager et al, 2005). ABCG2 is a major transporter for MTX that can be directly inhibited by DEX and MPRED, but apparently not by prednisolone (Pavek et al, 2005). In the present study, MTX resistance was also negatively correlated with ASP resistance. The data therefore suggest that for patients who show resistance to glucocorticoids and ASP (e.g. at relapse), treatment with MTX may be increasingly relevant. Further work is required to confirm the observed reciprocity between these drugs but, if genuine, the finding has direct implications for the clinical setting and the design of protocols for relapsing patients.

\section{ACKNOWLEDGEMENTS}

The authors would like to thank Dr David Baker (Princess Margaret Hospital), Professor Michael Garlepp (Curtin University of Technology School of Pharmacy) and Dr Ashleigh Murch and Marcia Watson (King Edward Memorial Hospital) for their invaluable contribution to the project, as well as the patients and parents with whom this study is connected. This research was funded by the NHMRC and the Children's Leukaemia and Cancer Research Foundation, Western Australia.

Supplementary Information accompanies the paper on British Journal of Cancer website (http://www.nature.com/bjc)

\section{REFERENCES}

Adamson PC, Poplack DG, Balis FM (1994) The cytotoxicity of thioguanine vs mercaptopurine in acute lymphoblastic leukemia. Leukemia Res 18: $805-810$

Alley MC, Scudiero DA, Monks A, Hursey ML, Czerwinski MJ, Fine DL, Abbott BJ, Mayo JG, Shoemaker RH, Boyd MR (1988) Feasibility of drug screening with panels of human tumor cell lines using a microculture tetrazolium assay. Cancer Res 48: 589-601

Balis FM, Holcenberg JS, Poplack DG, Ge J, Sather HN, Murphy RF, Ames MM, Waskerwitz MJ, Tubergen DG, Zimm S, Gilchrist GS, Bleyer WA (1998) Pharmacokinetics and pharmacodynamics of oral methotrexate and mercaptopurine in children with lower risk acute lymphoblastic leukemia: a joint children's cancer group and pediatric oncology branch study. Blood 92: $3569-3577$

Catts VS, Farnsworth ML, Haber M, Norris MD, Lutze-Mann LH, Lock RB (2001) High level resistance to glucocorticoids associated with a dysfunctional glucocorticoid receptor in childhood acute lymphoblastic leukemia cells selected for methotrexate resistance. Leukemia 15: 929-935

Cooperman J, Neely R, Teachey DT, Grupp S, Choi JK (2004) Cell division rates of primary human precursor B cells in culture reflect in vivo rates. Stem Cells 22: $1111-1120$

Drexler HG, Dirks WG, Matsuo Y, MacLeod RA (2003) False leukemialymphoma cell lines: an update on over 500 cell lines. Leukemia 17: 416-426

Drexler HG, Matsuo Y (1999) Guidelines for the characterization and publication of human malignant hematopoietic cell lines. Leukemia 13: $835-842$

Drexler HG, Uphoff CC, Dirks WG, MacLeod RA (2002) Mix-ups and mycoplasma: the enemies within. Leukemia Res 26: 329-333

Duyn AE, Kaspers GJ, Pieters R, Van Zantwijk CH, Broekema GJ, Hahlen K, Veerman AJ (1999) Effects of interleukin 3, interleukin 7, and B-cell growth factor on proliferation and drug resistance in vitro in childhood acute lymphoblastic leukemia. Ann Hematol 78: 163-171

Fine BM, Kaspers GJ, Ho M, Loonen AH, Boxer LM (2005) A genome-wide view of the in vitro response to L-asparaginase in acute lymphoblastic leukemia. Cancer Res 65: $291-299$

Hegge IR, Kaspers GJ, Rots MG, Jansen G, Pieters R, Veerman AJ (1999) Lack of cross-resistance between prednisolone and methotrexate in childhood acute lymphoblastic leukemia? A preliminary analysis. $A d v$ Exp Med Biol 457: 551-555

Hirt A, Werren EM, Luethy AR, Gerdes J, Wagner HP (1992) Cell cycle analysis in lymphoid neoplasia of childhood: differences among immunologic subtypes and similarities in the proliferation of normal and leukaemic precursor B cells. Br J Haematol 80: 189-193
Holleman A, Den Boer ML, Kazemier KM, Janka-Schaub GE, Pieters R (2003) Resistance to different classes of drugs is associated with impaired apoptosis in childhood acute lymphoblastic leukaemia. Blood 102: $4541-4546$

Kager L, Cheok M, Yang W, Zaza G, Cheng Q, Panetta JC, Pui CH, Downing JR, Relling MV, Evans WE (2005) Folate pathway gene expression differs in subtypes of acute lymphoblastic leukemia and influences methotrexate pharmacodynamics. J Clin Invest 115: $110-117$

Kamb A (2005) What's wrong with our cancer models? Nat Rev Drug Discov 4: $161-165$

Kaspers GJ, Pieters R, Van Zantwijk CH, Van Wering ER, Van Der DoesVan Den Berg A, Veerman AJ (1998) Prednisolone resistance in childhood acute lymphoblastic leukemia: vitro-vivo correlations and cross-resistance to other drugs. Blood 92: 259-266

Kaspers GJ, Veerman AJ, Pieters R, Van Zantwijk CH, Smets LA, Van Wering ER, Van Der Does-Van Den Berg A (1997) In vitro cellular drug resistance and prognosis in newly diagnosed childhood acute lymphoblastic leukemia. Blood 90: 2723-2729

Kaspers GJ, Wijnands JJ, Hartmann R, Huismans L, Loonen AH, Stackelberg A, Henze G, Pieters R, Hahlen K, Van Wering ER, Veerman AJ (2005) Immunophenotypic cell lineage and in vitro cellular drug resistance in childhood relapsed acute lymphoblastic leukaemia. Eur J Cancer 41: $1300-1303$

Kees UR (1987) Resistance to 1-beta-D-arabinofuranosylcytosine after highdose treatment childhood lymphoblastic leukemia: isolation of a drug resistant and a sensitive cell line. Cancer Res 47: 3088-3091

Kees UR, Campbell LJ, Ford J, Willoughby ML, Peroni SE, Ranford PR, Garson OM (1995) New translocation $\mathrm{t}(2 ; 13)(\mathrm{p} 12 ; \mathrm{q} 34)$ and rearrangement of the MLL gene in a childhood leukemia cell line. Genes Chromosomes Cancer 12: $201-208$

Kees UR, Ford J, Dawson VM, Piall E, Aherne GW (1989a) Development of resistance to 1-beta-D-arabinofuranosylcytosine after high-dose treatment in childhood lymphoblastic leukemia: analysis of resistance mechanism in established cell lines. Cancer Res 49: 3015-3019

Kees UR, Ford J, Price PJ, Meyer BF, Herrmann RP (1987) PER-117: a new human ALL cell line with an immature thymic phenotype. Leukemia Res 11: $489-498$

Kees UR, Ford J, Watson M, Murch A, Ringner M, Walker RL, Meltzer P (2003) Gene expression profiles in a panel of childhood leukemia cell lines mirror critical features of the disease. Mol Cancer Ther 2: $671-677$

Kees UR, Lukeis R, Ford J, Garson OM (1989b) Establishment and characterization of a childhood T-cell acute lymphoblastic leukemia cell 
line, PER-255, with chromosome abnormalities involving 7q32-34 in association with $\mathrm{T}$-cell receptor-beta gene rearrangement. Blood 74: $369-373$

Kees UR, Lukeis R, Ford J, Willoughby ML, Garson OM (1990) Establishment and characterization of a childhood pre-B acute lymphoblastic leukemia cell line, PER-278, with chromosome translocations $\mathrm{t}(1 ; 19)$ and $\mathrm{t}(1 ; 9)$. Cancer Genet Cytogenet 46: $201-208$

Kennedy MA, Gonzalez-Sarmiento R, Kees UR, Lampert F, Dear N, Boehm T, Rabbitts TH (1991) HOX11, a homeobox-containing T-cell oncogene on human chromosome 10q24. Proc Natl Acad Sci U S A 88: 8900-8904

Klumper E, Pieters R, Veerman AJ, Huismans DR, Loonen AH, Hahlen K, Kaspers GJ, van Wering ER, Hartmann R, Henze G (1995) In vitro cellular drug resistance in children with relapsed/refractory acute lymphoblastic leukemia. Blood 86: $3861-3868$

Kobayashi H, Takemura Y, Holland JF, Ohnuma T (1998) Vincristine saturation of cellular binding sites and its cytotoxic activity in human lymphoblastic leukemia cells: mechanism of inoculum effect. Biochem Pharmacol 55: $1229-1234$

Lofgren C, Hjortsberg L, Blennow M, Lotfi K, Paul C, Eriksson S, Albertioni F (2004) Mechanisms of cross-resistance between nucleoside analogues and vincristine or daunorubicin in leukemic cells. Biochem Biophys Res Commun 320: $825-832$

Martin-Aragon S, Mukherjee SK, Taylor BJ, Ivy SP, Fu CH, Ardi VC, Avramis VI (2000) Cytosine arabinoside (ara-C) resistance confers crossresistance or collateral sensitivity to other classes of anti-leukemic drugs. Anticancer Res 20: 139-150

Masters JR (2000) Human cancer cell lines: fact and fantasy. Nat Rev Mol Cell Biol 1: $233-236$

Masters JR, Thomson JA, Daly-Burns B, Reid YA, Dirks WG, Packer P, Toji LH, Ohno T, Tanabe H, Arlett CF, Kelland LR, Harrison M, Virmani A, Ward TH, Ayres KL, Debenham PG (2001) Short tandem repeat profiling provides an international reference standard for human cell lines. Proc Natl Acad Sci USA 98: $8012-8017$

Medh RD, Webb MS, Miller AL, Johnson BH, Fofanov Y, Li T, Wood TG, Luxon BA, Thompson EB (2003) Gene expression profile of human lymphoid CEM cells sensitive and resistant to glucocorticoid-evoked apoptosis. Genomics 81: $543-555$

Mihal V, Hajduch M, Noskova V, Janostakova A, Safarova M, Orel M, Kouzmina G, Stary J, Blazek B, Pospisilova D (2004) The analysis of correlations between drug resistance and clinical/laboratory measures found in a group of children with all treated by ALL-BFM 90 protocol. Bull Cancer 91: E80-E89

Pavek P, Merino G, Wagenaar E, Bolscher E, Novotna M, Jonker JW, Schinkel AH (2005) Human breast cancer resistance protein: interactions with steroid drugs, hormones, the dietary carcinogen 2-amino-1-methyl6-phenylimidazo(4,5-b)pyridine, and transport of cimetidine. J Pharmacol Exp Ther 312: $144-152$

Pieters R, den Boer ML, Durian M, Janka G, Schmiegelow K, Kaspers GJ, van Wering ER, Veerman AJ (1998) Relation between age, immunophenotype and in vitro drug resistance in 395 children with acute lymphoblastic leukaemia - implications for treatment of infants. Leukemia 12: $1344-1348$

Pieters R, Huismans DR, Loonen AH, Hahlen K, van der Does-van den Berg A, van Wering ER, Veerman AJ (1991) Relation of cellular drug resistance to long-term clinical outcome in childhood acute lymphoblastic leukaemia. Lancet 338: 399-403

Pieters R, Klumper E, Kaspers GJ, Veerman AJ (1997) Everything you always wanted to know about cellular drug resistance in childhood acute lymphoblastic leukemia. Crit Rev Oncol Hematol 25: 11-26

Pieters R, Loonen AH, Huismans DR, Broekema GJ, Dirven MW, Heyenbrok MW, Hahlen K, Veerman AJ (1990) In vitro drug sensitivity of cells from children with leukemia using the MTT assay with improved culture conditions. Blood 76: 2327-2336

Ramakers-van Woerden NL, Pieters R, Loonen AH, Hubeek I, van Drunen E, Beverloo HB, Slater RM, Harbott J, Seyfarth J, van Wering ER, Hahlen K, Schmiegelow K, Janka-Schaub GE, Veerman AJ (2000) TEL/AML1 gene fusion is related to in vitro drug sensitivity for L-asparaginase in childhood acute lymphoblastic leukemia. Blood 96: $1094-1099$

Rots MG, Pieters R, Peters GJ, Noordhuis P, Van Zantwijk CH, Henze G, Janka-Schaub GE, Veerman AJ, Jansen G (2000) Methotrexate resistance in relapsed childhood acute lymphoblastic leukaemia. Br J Haematol 109: $629-634$

Steinbach D, Friedrich J, Dawczynski K, Furchtbar S, Gruhn B, Wittig S, Zintl F, Sauerbrey A (2005) Are MTT assays the right tool to analyze drug resistance caused by $\mathrm{ABC}$-transporters in patient samples? Leukemia Lymphoma 46: $1357-1363$

Styczynski J, Pieters R, Huismans DR, Schuurhuis GJ, Wysocki M, Veerman AJ (2000) In vitro drug resistance profiles of adult versus childhood acute lymphoblastic leukaemia. Br J Haematol 110: 813 -818

Styczynski J, Wysocki M, Debski R, Balwierz W, Rokicka-Milewska R, Matysiak M, Balcerska A, Kowalczyk J, Wachowiak J, Sonta-Jakimczyk D, Chybicka A (2002) Cross-resistance to five glucocorticoids in childhood acute lymphoblastic and non-lymphoblastic leukemia samples tested by the MTT assay: preliminary report. Acta Biochim Pol 49: $93-98$

Styczynski J, Wysocki M, Debski R, Czyzewski K, Balwierz W, Juraszewska E, Matysiak M, Malinowska I, Stanczak E, Sonta-Jakimczyk D, Szczepanski T, Wachowiak J, Konatkowska B, Balcerska A, Ploszynska A, Kowalczyk J, Stefaniak J, Badowska W, Wieczorek M, Olejnik I, Krawczuk-Rybak M, Kuzmicz M (2005) In vitro sensitivity of leukemic cells to nucleoside derivatives in childhood acute leukemias: good activity in leukemic relapses. Neoplasma 52: 74-78

van der Heijden J, de Jong MC, Dijkmans BA, Lems WF, Oerlemans R, Kathmann I, Scheffer GL, Scheper RJ, Assaraf YG, Jansen G (2004) Acquired resistance of human $\mathrm{T}$ cells to sulfasalazine: stability of the resistant phenotype and sensitivity to non-related DMARDs. Ann Rheum Dis 63: $131-137$

Whitman SP, Strout MP, Marcucci G, Freud AG, Culley LL, Zeleznik-Le NJ, Mrozek K, Theil KS, Kees UR, Bloomfield CD, Caligiuri MA (2001) The partial nontandem duplication of the MLL (ALL1) gene is a novel rearrangement that generates three distinct fusion transcripts in B-cell acute lymphoblastic leukemia. Cancer Res 61: 59-63

Zwaan CM, Kaspers GJ, Pieters R, Ramakers-Van Woerden NL, den Boer ML, Wunsche R, Rottier MM, Hahlen K, van Wering ER, Janka-Schaub GE, Creutzig U, Veerman AJ (2000) Cellular drug resistance profiles in childhood acute myeloid leukemia: differences between FAB types and comparison with acute lymphoblastic leukemia. Blood 96: 2879-2886 